PARALLEL PLANNING MECHANISMS AS A "RECIPE FOR DISASTER"

ISSN 1727-3781

2010 VOLUME 13 No 1 


\section{PARALLEL PLANNING MECHANISMS AS A "RECIPE FOR DISASTER"}

\section{J Van Wyk}

\section{Introduction}

Township establishment in South Africa takes place in terms of the provincial Ordinances of the "old" South Africa. The process, which is overseen by municipalities, is a lengthy one, sometimes taking up to three years before a township is ready for occupation. This practice frustrates developers, tired of waiting for approvals and eager to provide exclusive high-income developments. However, a loophole was provided by the Development Facilitation Act 67 of $1995 .{ }^{1}$ Soon after its enactment developers discovered that instead of going the municipal route, they could apply for permission from provincial development tribunals to establish so-called land development areas in terms of the less cumbersome chapters $\mathrm{V}$ and $\mathrm{VI}$ of the DFA. ${ }^{2}$ This practice was met with concern and criticism in many quarters, mainly because applying DFA and Ordinance procedures in parallel causes considerable headaches for municipal planning departments in whose areas of jurisdiction the developments are located. ${ }^{3}$

\footnotetext{
Jeannie van Wyk. BBibl (UP); LLB (Unisa); LLM (UWits); LLD (Unisa). Professor, Department of Private Law, UNISA.

Hereafter the DFA.

Kidd and Retief "Environmental Assessment" 1022; Badenhorst et al The Law of Property 661; Van Wyk 2002 SAPL 174-176; Van Wyk 2005 StellLR 483.

3 Wise Land Use: White Paper on Spatial Planning, Land Use Management and Land Development GG 22473 of 20 July 2001 69; Carey Miller Land Title in South Africa 412.
} 
The problem was resolved by the recent landmark decision in City of Johannesburg Metropolitan Municipality $v$ Gauteng Development Tribuna/ ${ }^{4}$ which lay to rest all the negative consequences of employing DFA procedures alongside those of the provincial Ordinances to establish townships (or to use DFA parlance, "land development areas"). The crux of the decision is captured in the following observation by Nugent JA:

The existence of parallel authority in the hands of two different bodies, with its potential for the two bodies to speak with different voices on the same subject matter, cannot but be disruptive to orderly planning and development within a municipal area. ${ }^{5}$

This welcome and timely decision of the SCA has declared invalid chapters $\mathrm{V}$ and $\mathrm{VI}$ of the DFA. Moreover, it has formalised planning terminology in South Africa, delineated the boundaries of "municipal planning" and "urban planning and development" as listed in Schedules 4 and 5 of the Constitution ${ }^{6}$ and, in the process, clarified the structure of planning law.

This note will examine the decision of the SCA and focus on the role it will clearly have in reforming some of the law relating to planning. It will look at the facts of the case, uncertainties around terminology, the structure of planning in South Africa, the content of municipal planning, the role of the DFA and the consequences of the declaration of invalidity by the SCA.

\section{$2 \quad$ Facts}

The case originated in the attempts by the City of Johannesburg Metropolitan Municipality ${ }^{7}$ to perform its statutory functions in regard to municipal planning without the interference of the Gauteng Development Tribunal. It is clear from the judgment that the CoJ made attempts to resolve the disruption caused by Metropolitan Municipality (SCA) case.

$5 \quad$ City of Johannesburg Metropolitan Municipality (SCA) case par 1.

6 Constitution of the Republic of South Africa, 1996. Hereafter Constitution.

7 Hereafter CoJ. 
decisions of the Tribunal in the spirit of cooperative governance (as required by chapter 3 of the Constitution), but to no avail. During the course of the judgment, Nugent JA refers to three examples which lead to the conundrum.

The first was a case where the tribunal approved the rezoning of a single residential property in Linden, a CoJ suburb, to allow a restaurant and gift shop - eliciting the comment from Nugent JA that it was difficult to imagine "why an application that is quintessentially of local interest should have been considered to be appropriate to a provincial tribunal". ${ }^{8}$ The other two cases relate to township developments under the jurisdiction of the CoJ. The one was an application by Ivory Palm Properties $20 \mathrm{CC}$, the owner and developer of Portion 229 (a portion of portion 75 of the farm Roodekrans 183 IQ). The developer applied to the Gauteng Development Tribunal to establish a township, to be known as Poortview Extension 19, comprising 21 erven of which 19 would be zoned "Residential 1", one "agricultural" and one "special" for the purposes of access to the township. At the time the application was made the land was zoned "agricultural". The zoning did not permit residential development or township establishment and the property fell outside the municipality's urban development boundary. ${ }^{9}$ The municipality opposed the application on the grounds that the use would be inconsistent with and compromise the town planning scheme, the integrated development plan, the applicable spatial development frameworks and the urban development boundary. Despite the objections the application was approved by the Gauteng Development Tribunal in August 2004.

The other and similar application related to Portion 228 of the farm Ruimsig 265 IQ. The developers and owners applied for the establishment of a land development area in terms of the DFA. Similar to the Roodekrans development the zoning was "agricultural", it did not permit residential development or

$8 \quad$ Johannesburg Metropolitan Municipality v Gauteng Development Tribunal 20084 SA 572 (W) par 19. Hereafter the Johannesburg Metropolitan Municipality (W) case.

9 Johannesburg Metropolitan Municipality (W) case par 93. 
township establishment and the property fell outside the municipality's urban development boundary. ${ }^{10}$ The municipality also opposed this application, the grounds being similar to the Roodekrans application. Once again the Gauteng Development Tribunal granted the application in September 2004.

In August 2005 the CoJ unilaterally, and without any warning, announced that it would no longer recognize approvals in terms of the DFA. Simultaneously it brought an application in the (now) South Gauteng High Court for declaratory orders relating to the powers which the Gauteng Development Tribunal and the Gauteng Development Tribunal Appeals Tribunal have under the DFA to amend town planning schemes and to approve the establishment of townships. It further applied for a review and setting aside of these decisions and for an order interdicting the developers from using the Roodekrans and Ruimsig properties for the establishment of land development areas. All the applications were unsuccessful.

Gildenhuys $\mathrm{J}$, in the court a quo, ${ }^{11}$ decided that the DFA was in fact parallel legislation which could be employed alternatively to the procedure set out in the provincial Ordinances. The statement by Budlender, Latsky and Roux ${ }^{12}$ that the land development procedures in terms of the DFA "will operate in parallel to and as alternatives for existing land development procedures" weighed heavily in informing the decision of Gildenhuys $\mathrm{J}^{13}$ The CoJ then appealed to the SCA, where the principal issue to be determined was the constitutionality of chapters $\mathrm{V}$ and $\mathrm{VI}$ of the DFA. ${ }^{14}$

10 Johannesburg Metropolitan Municipality (W) case par 99.

11 Johannesburg Metropolitan Municipality (W) case.

12 Juta's New Land Law 2A-3.

13 See also Classen "Spatial planning" 928; Glazewski Environmental Law 207.

14 City of Johannesburg Metropolitan Municipality (SCA) case par 4. 


\section{Decision of the SCA}

In deciding that chapters $\mathrm{V}$ and $\mathrm{VI}$ of the DFA were unconstitutional the SCA expanded on the manner in which land use is regulated under the provincial Ordinances and related legislation ${ }^{15}$ as well as the parallel powers that are given to provincial development tribunals in terms of the DFA. ${ }^{16}$ It looked at the structure of government and showed how certain powers of government are conferred directly on the lower tiers of government. ${ }^{17}$ The only real issue in dispute was whether the authority that municipalities exercise under the Ordinances falls within one of the functional areas as set out in Schedules 4 and 5 of the Constitution. ${ }^{18}$ More specifically the court had to decide whether the functional area described as "municipal planning" includes the functions that are performed by municipalities as outlined. If so, these are matters reserved to municipalities and cannot be assigned to another body such as a development tribunal. ${ }^{19}$ The court referred to the functional area of "urban and regional development" listed in Schedule 4 and the interpretation given to it by the court a quo ${ }^{20}$ which was that development is primarily a national and provincial competence and municipal involvement therein is limited to planning for it, promoting it and participating therein. ${ }^{21}$ This reasoning, according to Nugent JA, would amount to approaching the matter the wrong way around. ${ }^{22}$

Moreover, the Constitution could never have been framed

... so as to confine the powers of a municipality to conceiving and preparing plans in the abstract, with no power to implement them. ... It is suggested

City of Johannesburg Metropolitan Municipality (SCA) case pars 5-11. See also 5.2 below.

16 City of Johannesburg Metropolitan Municipality (SCA) case pars 13-18. See also 6.2 below.

17 City of Johannesburg Metropolitan Municipality (SCA) case pars 24-29. See also 5.1 below.

18 City of Johannesburg Metropolitan Municipality (SCA) case par 28.

19 City of Johannesburg Metropolitan Municipality (SCA) case par 30.

20 City of Johannesburg Metropolitan Municipality (SCA) case pars 31-35.

21 Johannesburg Metropolitan Municipality (W) case par 56. See City of Johannesburg Metropolitan Municipality (SCA) case par 33.

22 City of Johannesburg Metropolitan Municipality (SCA) case par 35. 
in the judgment of the court below that abstract planning of that kind (without implementation) might have a use in enabling a municipality to assist and participate in development that is undertaken by (or at the behest of) provincial and national government. I fail to see what purpose would be served by reserving power to local government merely to assist or participate in the exercise of powers by another tier of government. ${ }^{23}$

After examining terminology ${ }^{24}$ the court finds that "planning" refers to the control and regulation of land use and the prefix "municipal" restricts it to municipal affairs. These include the functions assigned to municipalities under the provincial Ordinances. The broad terms in which chapters $\mathrm{V}$ and $\mathrm{VI}$ of the DFA are couched cannot function in that context. Consequently "urban and regional development" is left in the hands of national and provincial government. ${ }^{25}$

The court found that it would not be possible to declare invalid only specific words, phrases or sections and declared chapters $\mathrm{V}$ and $\mathrm{VI}$ invalid in their entirety. ${ }^{26}$

\section{$4 \quad$ Terminology}

An important aspect of the SCA judgment concerns terminology. In South Africa there has always been confusion about which term describes the discipline dealing with the law relating to land use planning and management.

In 1999 the term "planning law" was mooted to describe this discipline. The reasons for using this term were that it reflected international practice and it was wide enough to encompass all the aspects of the discipline including the important social aspect. ${ }^{27}$

23 City of Johannesburg Metropolitan Municipality (SCA) case par 38.

24 See 4 below.

25 City of Johannesburg Metropolitan Municipality (SCA) case pars 41-43.

26 City of Johannesburg Metropolitan Municipality (SCA) case par 43. See also 7 below.

27 Van Wyk Planning Law 3-5. 
However, a host of other terms was always employed to describe this area of the law. These include "land use planning law", "spatial planning law" and "physical planning law". The White Paper entitled Wise Land Use: White Paper on Spatial Planning, Land Use Management and Land Development continued the trend by suggesting that the term "integrated development planning" be used to denote the idea of plan creation (also known as forward planning) whilst the terms "land use management" and "land development" be used to denote change in land use (also known as development control). ${ }^{28}$

In the SCA judgment, Nugent JA refers to Wary Holdings (Pty) Ltd $v$ Stalwo (Pty) $L t d^{\not 9}$ where Yacoob $\mathrm{J}$, in an important dissenting judgment, makes a significant contribution to the debate on terminology describing "planning" in the context of planning functions set out in the Constitution. ${ }^{30}$ Against the background of Yacoob J's views he has now put closure on the terminology debate with the statement that "... it has become commonplace throughout the English-speaking world to use the word "planning" to describe the regulation and control of land use". ${ }^{31}$

Moreover, says Nugent JA,

It is clear that the word "planning" when used in the context of municipal affairs, is commonly understood to refer to the control and regulation of land use, and I have no doubt that it was used in the Constitution with that common usage in mind. The prefix "municipal" does no more than confine it to municipal affairs. That construction, which gives meaningful effect to the term, has the effect of leaving in the hands of national and provincial government the authority to legislate in the functional area of "urban ... development', but reserving to municipalities the authority to micro-manage the use of land for any such development. ${ }^{32}$

At 65.

20091 SA 337 (CC) par 131. Hereafter Wary Holdings (Pty) Ltd case.

City of Johannesburg Metropolitan Municipality (SCA) case par 127.

City of Johannesburg Metropolitan Municipality (SCA) case par 40.

City of Johannesburg Metropolitan Municipality (SCA) case par 41.

$220 / 234$ 
It should be noted that the SCA's clarification of planning terminology is of more than academic interest. It formed a crucial part of the court's interpretation of the provisions of Schedules 4 and 5 of the Constitution, and the conclusion it reached on the legislative powers of national and provincial legislatures in respect of planning at municipal level.

\section{$5 \quad$ Structure of planning in South Africa}

The quoted statement of Nugent JA is also applicable to the structure of planning in South Africa. It is especially relevant to investigate the relationship between "urban and rural development" and "municipal planning" as listed in Schedules 4 and 5 of the Constitution for it is the analysis of this distinction which comprises one of the crucial differences in the decisions of Gildenhuys $J$ in the court a quo and Nugent JA in the SCA.

\subsection{Constitutional framework}

The Constitution sets out the legislative authority of all three spheres of government. ${ }^{33}$ In this regard, Schedules 4 and 5 of the Constitution bear specific significance. Schedule 4 contains a list of matters over which parliament and provincial legislatures have concurrent legislative authority. "Regional planning and development" and "urban and rural development" are listed as areas of concurrent legislative competence in Schedule 4 Part A. Provincial legislatures may pass legislation on matters listed in Schedules 4 and 5 of the Constitution. ${ }^{34}$ "Provincial planning" is an exclusive provincial functional area listed in Schedule 5 Part A. Municipal councils may make and administer by-laws on matters listed in Part B of Schedules 4 and 5 
respectively. ${ }^{35}$ "Municipal planning" is listed in Part B of Schedule 4. Against the background of these legislative competences the SCA decision makes a contribution in determining the content of "municipal planning".

\subsection{Municipal planning}

The SCA indicates that the introduction and enforcement, by a municipality, of a town planning scheme is its primary tool for regulating land use. ${ }^{36}$ Furthermore, a municipality is entitled to decide whether and on what conditions townships may be established within its municipal area. ${ }^{37}$ These examples distinguish the following two sub-disciplines of planning:

(a) Land use planning (also referred to as integrated development planning, forward planning or plan creation). Plans can either be policy plans or regulatory plans. Policy plans include integrated development plans, structure plans and spatial development frameworks while regulatory plans include zoning schemes, land use management plans or town planning schemes. Included in the planning function is a determination of the size of erven in certain areas, the determination of building restrictions and the imposition of height restrictions.

(b) Land use management and land development (also referred to as development control or changes in the use of land). A variety of procedures is envisaged here, namely the foundation and development of new townships, the removal of restrictions, the removal or amendment of conditions of title, the granting of so-called consent uses, subdivision of land and consolidation of land.

35 S 156(1)-(2).

36 City of Johannesburg Metropolitan Municipality (SCA) case par 6.

37 City of Johannesburg Metropolitan Municipality (SCA) case par 8.

222 / 234 
A comprehensive legislative structure is necessary to address all these functions of municipalities. This structure is referred to by both Yacoob $\mathrm{J}$ in the Wary Holdings (Pty) Ltd decision ${ }^{38}$ and Nugent JA in the Johannesburg Metropolitan Municipality decision ${ }^{39}$ in similar vein. It is the following:

The Local Government: Municipal Systems Act 32 of 2000 requires municipalities to adopt a single, inclusive and strategic plan for the development of its municipality. ${ }^{40}$ This is the Integrated Development Plan, ${ }^{41}$ one of the components of which is the Spatial Development Framework. ${ }^{42}$ Details of the SDF are contained in the Local Government: Municipal Planning and Performance Management Regulations. ${ }^{43}$ The SDF must set out the objectives that reflect the desired spatial form of the municipality and contain strategies to achieve the desired form. These strategies must indicate desired patterns of land use within the municipality, address the spatial reconstruction of the municipality, relate to the location and nature of development in the municipality ${ }^{44}$ and set out the basic guidelines for a land use management system in the municipality. ${ }^{45}$ The town planning and townships Ordinances of the erstwhile provinces ${ }^{46}$ are all still applicable and contain detailed provisions regarding the creation of town planning schemes, referred to by Nugent JA as "the the principal tool for regulating land use", and the establishment of townships. Besides these Ordinances the provinces still apply the following legislation:

38 Pars 132-137.

39 City of Johannesburg Metropolitan Municipality (SCA) case pars 5-12.

40 S 25.

41 Hereafter IDP.

42 Hereafter SDF. See s 26(e) of the Local Government: Municipal Systems Act 32 of 2000.

43 GN R 796 GG 22605 of 24 August 2001.

$44 \mathrm{Cl} 2(4)(\mathrm{c})$.

$45 \mathrm{Cl} 2(4)(\mathrm{d})$.

46 Town Planning Ordinance 27 of 1949 (N); Townships Ordinance 9 of 1969 (OFS); Land Use Planning Ordinance 15 of 1985 (C); Town-planning and Townships Ordinance 15 of $1986(\mathrm{~T})$. 
(a) Regulations enacted in terms of the Black Communities Development Act 4 of $1984^{47}$ and the Black Administration Act 38 of $1927^{48}$ which, despite the repeal of the principal Acts, remain in operation.

(b) Legislation of the erstwhile 'homelands' such as KwaZulu-Natal, Gazankulu, KaNgwane, Lebowa, KwaNdebele and QwaQwa.

(c) Legislation of the so-called TBVC states of Transkei, Bophuthatswana, Venda and Ciskei. ${ }^{49}$

A comprehensive land use regime, such as the one described, calls for interrelated and coordinated action on the part of the various departments and functionaries of a municipality if its objectives are to be achieved. To introduce into that ongoing process a third party, such as a DFA development tribunal,

with the power to intervene and impose its own decisions that might be inconsistent with the decisions and objectives of the municipality is a recipe for chaos. That is what is purportedly authorised by chapters $\mathrm{V}$ and $\mathrm{VI}$ of the Act. ${ }^{50}$

It is, therefore, clear from Nugent JA's decision that the DFA is not part of municipal planning.

\subsection{Urban and rural development}

The certainty that Nugent JA provides regarding the content of "municipal planning" facilitates a determination of the content of "urban and rural development." This functional area is listed as an area of concurrent national and provincial legislative competence in Schedule 4 Part A. Since the SCA

47 Proc R1897 of 1986: Regulations Relating to Township Establishment and Land Use.

48 GN R1886 of 1990: Township Development Regulations for Towns; GN R1888 of 1990: Land Use and Planning Regulations.

49 See further van Wyk Planning Law 55.

50 City of Johannesburg Metropolitan Municipality (SCA) case par 12. 
indicates that the authority to legislate in the functional area of "urban and rural development" is left in the hands of national and provincial government the important issue is then what the content of this functional area is. Nugent JA gives some assistance by indicating that it could include "the establishment of financing schemes for development, the creation of bodies to undertake housing schemes or to build urban infrastructure, the setting of development standards to be applied by municipalities, and so on". ${ }^{51}$

\section{The DFA}

\subsection{Purpose}

The DFA originated in the National Housing Forum which was investigating ways to alleviate problems related to the delivery of low income housing. ${ }^{52}$ It was promulgated in 1995, at a time in South Africa when land reform was the main topic on the (then) Department of Land Affairs' agenda and classified as land redistribution legislation. ${ }^{53}$

The long title of the DFA indicates that its purpose is:

to introduce extraordinary measures to facilitate and speed up the implementation of reconstruction and development programmes and projects in relation to land...to provide for nationally uniform procedures for the subdivision and development of land in urban and rural areas so as to promote the speedy provision and development of land for residential, small-scale farming or other needs and uses ...

Lewis JA, in a separate judgment in the Johannesburg Metropolitan Municipality case, indicates that the long title of the DFA

...is not meant for municipal planning in the strict sense. Its purpose is to redress inequalities left by a policy of separate development, where people 
of different races were physically divided and whose housing and property were vastly unequal. Hence the need for reconstruction and development at a pace that might not be accommodated within the framework of ordinances regulating normal municipal planning. ${ }^{54}$

Not only its long title but other provisions in the DFA, especially chapter II, containing general principles for land development and conflict resolution, point towards its purpose as an Act geared towards addressing the imbalances of the past and to fast track the delivery of RDP housing. ${ }^{55}$

\subsection{Land development}

Chapters V and VI of the Act, declared invalid by the SCA, contain extensive procedures for land development in both an urban and a rural context. In brief an applicant must lodge an application with the designated officer and must give notice of the application to prescribed persons or bodies. ${ }^{56}$ The designated officer must consider the application, any comments and representations ${ }^{57}$ and submit the application to a provincial development tribunal, ${ }^{58}$ which in turn must consider the application. ${ }^{59}$

Initially the establishment of land development areas in terms of the DFA was seen through a land reform lens. This is clear from the courts' views of the Act in cases such as Port Elizabeth Municipality $v$ Peoples Dialogue on Land and Shelter ${ }^{60}$ where Horn AJ states that the DFA instructs the state and local

54 City of Johannesburg Metropolitan Municipality (SCA) case par 59.

55 White Paper on South African Land Policy (1997) 37; Carey Miller Land Title in South Africa 304, 411-412; Van Wyk Planning Law 141-142; Van Wyk 2006 SAPL 377; Van Wyk 2005 StellLR 483. See also City of Johannesburg Metropolitan Municipality (SCA) case par 13 .

56 Ss 31 and 49. See also City of Johannesburg Metropolitan Municipality (SCA) case par 17; Glazewski Environmental Law 210-211; Carey Miller Land Title in South Africa 424430; Kidd and Retief "Environmental Assessment" 1022-1023; Van Wyk Planning Law 144-146.

57 Ss 32 and 50.

58 Ch III.

59 Ss 33 and 51. See also City of Johannesburg Metropolitan Municipality (SCA) case par 18.

6020002 SA 1074 (SEC) 1084C. 
authorities "...to give priority to the needs of the poor" and Minister of Public Works $v$ Kyalami Ridge Environmental Association ${ }^{61}$ where Chaskalson P describes the purpose of the DFA as being "the establishment of informal townships of a permanent nature in which lots may be acquired and sold".

However, it was not long before developers who wished to establish non-land reform townships took advantage of the loophole and employed the provisions of the DFA to establish upmarket residential townships as well as game and golf estates. ${ }^{62}$ The reasons are varied and include the fact that the DFA is supposedly a quicker means of establishing a township ${ }^{63}$ and that it contains provisions which make it possible to exempt, from certain of its provisions, specified legislation such as the Subdivision of Agricultural Land Act 70 of $1970 .{ }^{64}$ This is not possible in terms of the Ordinances and consent must be obtained from the Minister of Agriculture to subdivide agricultural land.

This practice of creating and conferring upon provincial tribunals the authority to approve land use applications that might be in conflict with a municipality's plans $^{65}$ led to the many problems which are at the root of the SCA decision.

\subsection{Repeal of the DFA}

According to the Wise Land Use: White Paper on Spatial Planning, Land Use Management and Land Development the DFA is an interim measure only, to be phased out on the promulgation of a proposed Land Use Management Act. ${ }^{66}$ This is also clear from the fact that the DFA never repealed any of the pre-1994 apartheid planning legislation. ${ }^{67}$ The policy set out in the White Paper was put

6120013 SA 1151 (CC) par 43.

62 Van Wyk 2007 SAPL 371-381.

63 "Developers challenge city over its move on key building Act" www.snymans.com

64 Van Wyk 2007 SAPL 371-381; West Feb 2003 De Rebus 59.

65 City of Johannesburg Metropolitan Municipality (SCA) case par 14.

66 68-69.

67 Memorandum on the Objects of the Land Use Management Bill, 2008. 
into practice with the publication of a draft Land Use Management Bill in the same Government Gazette. The draft Bill was made available with variations in June 2002, July 2003, January 2006 and March 2007. The latest Land Use Management Bill was published in April $2008^{68}$ and lists the DFA as one of the Acts to be repealed. ${ }^{69}$ The Bill was presented to the Portfolio Committee of the National Assembly in August 2008. However, there were numerous criticisms of the Bill and it was withdrawn. In the context of the SCA decision it will have to be re-introduced at a later stage.

\section{$7 \quad$ Declaration of invalidity}

Orders that declare legislation invalid usually become effective immediately and apply retrospectively to the date the Final Constitution became operative..$^{70}$ The CoJ asked the SCA to declare the legislation invalid with effect from 1 August 2005, the date upon which it informed the Gauteng Development Tribunal that its conduct was unlawful and would not be recognized by the municipality. However, the Constitution contains provisions limiting the effect of declarations of invalidity either by suspending the order or limiting the retrospective effect of the declaration of invalidity. ${ }^{71}$ The SCA indicates that a declaration of invalidity would cause considerable disruption because development tribunals would have made many decisions affecting rights in the course of their existence. ${ }^{72}$ Moreover, it would probably affect parties ignorant of the notice given by the municipality who continued to employ the provisions of the DFA. A declaration of invalidity having even limited retrospective effect would not be just and equitable.

Chaskalson et al "Constitutional Litigation" 3-28.

S 172(1).

City of Johannesburg Metropolitan Municipality (SCA) case par 45. 
The SCA therefore suggests that an appropriate order should be designed which would protect the validity of decisions made by development tribunals, that development tribunals be enabled to continue to perform their legitimate functions until the offending provisions have been replaced and that they restrict their activities to these legitimate functions. All of these suggestions must be seen against the background of the Constitution which provides that the Constitutional Court must make the final decision whether an Act of Parliament is constitutional and must confirm any order of invalidity made by the SCA before that order has any force. ${ }^{73}$

To that end the order made by the SCA is that the declaration of invalidity of chapters $\mathrm{V}$ and $\mathrm{VI}$ of the DFA is suspended for 18 months from the date of the order subject to the conditions that no development tribunal may accept for consideration or consider any application for the grant or alteration of land use rights in a municipal area, nor may any development tribunal on its own initiative amend any measure that regulates or controls land use within a municipal area. $^{74}$

\section{Conclusion}

The decision by the SCA is a timely one. It has brought certainty to a situation where there were widely diverging views on the parallel application of the DFA and the Ordinances. It somehow seems inconceivable that a purpose so clearly spelt out in the DFA itself and commented upon by the courts and academic writers could be overlooked so that non-land reform "land development areas" could be established. In this context development tribunals could be seen to be exercising their powers for an improper purpose..$^{75}$ Simultaneously though, development tribunals and academic writers were equally of the opinion that such a practice was permissible.

73 S 167(5).

74 City of Johannesburg Metropolitan Municipality (SCA) case par 50.

75 Hoexter Constitutional and Administrative Law 156-157. $229 / 234$ 
It seems ironic that the DFA, being a product of the new dispensation, should now be taking a back seat to legislation - the Ordinances - emanating from the previous apartheid based dispensation. If any occurrence were to trigger the urgent introduction of framework national land use planning legislation it would be this declaration of invalidity of chapters $\mathrm{V}$ and $\mathrm{VI}$ of the DFA. The impasse, since 2001, in introducing a Land Use Management Act must be resolved. The introduction of new national framework legislation will also give much needed impetus to the introduction of new provincial legislation. New legislation has been promulgated in some provinces in anticipation of new national legislation, but it is not being put into operation pending a national framework. Examples of such provincial legislation in waiting are the Gauteng Planning and Development Act 3 of 2003, the Western Cape Planning and Development Act 7 of 1999 and the KwaZulu-Natal Planning and Development Act 6 of 2008. ${ }^{76}$

The final word on this matter rests with the Constitutional Court which, in terms of the Constitution, ${ }^{77}$ must confirm the SCA's order of invalidity. The SCA ordered the appellant in the matter to promptly lodge the record of the matter with the Registrar of the Constitutional Court. It will indeed be interesting to see whether the highest court in the land can fault the carefully reasoned unanimous decision of the SCA.

76 Certain sections came into operation on 1 March 2009.

77 S 167(5). 


\section{Bibliography}

Badenhorst et al The Law of Property

Badenhorst P, Pienaar JM and Mostert H Silberberg and Schoeman's The law of property $5^{\text {th }}$ ed (Lexis Nexis Butterworths Durban 2006)

Budlender, Latsky and Roux Juta's New Land Law

Budlender G, Latsky J and Roux T Juta's New Land Law (Juta Cape Town 1998)

Carey Miller Land Title in South Africa

Carey Miller DL Land Title in South Africa (Juta Cape Town 2000)

Chaskalson et al "Constitutional Litigation"

Chaskalson A et al "Constitutional Litigation" in Woolman S et al (eds) Constitutional Law of South Africa $2^{\text {nd }}$ ed (Juta Cape Town 208-) 3-28

Claassen "Spatial Planning"

Claassen PE "Spatial planning with the Western Cape Province as a case study" in Strydom HA and King ND (eds) in Fuggle \& Rabie's Environmental management in South Africa $2^{\text {nd }}$ ed (Juta Cape Town 2009) 928-936

Glazewski Environmental Law

Glazewski J Environmental Law in South Africa $2^{\text {nd }}$ ed (Lexis Nexis Butterworths Durban 2005)

Hoexter Constitutional and Administrative Law

Hoexter C The New Constitutional and Administrative Law Vol 2 Administrative Law (Juta Cape Town 2002) 
Kidd and Retief "Environmental Assessment"

Kidd $\mathrm{M}$ and Retief $\mathrm{F}$ "Environmental Assessment" in Strydom HA \& King ND (eds) Fuggle \& Rabie's Environmental management in South Africa $2^{\text {nd }}$ ed (Juta Cape Town 2009) 971-1047

Scheepers Law and Development

Scheepers T A Practical Guide to Law and Development (Juta Cape Town 2000)

Van der Walt 1999 JCRDL

Van der Walt AJ "Roman law, fundamental rights and land reform in Southern Africa 1999 Journal of Contemporary Roman-Dutch Law 400422

Van Wyk 2002 SAPL

Van Wyk J "Development in protected areas" 2002 SA Public Law 163-177

Van Wyk 2005 Stell LR

Van Wyk $\mathrm{J}$ "The relationship (or not) between rights of access to land and housing: De-linking land from its components" 2005 Stellenbosch Law Review 466-487

Van Wyk 2007 SAPL

Van Wyk J "Getting golf estates right..." 2007 SA Public Law 371-381

Van Wyk Planning Law

Van Wyk J Planning Law (Cape Town Juta 1999)

West Feb 2003 De Rebus

West A "Consent or no consent?" 2003 De Rebus 59 


\section{Register of cases}

City of Johannesburg Metropolitan Municipality $v$ Gauteng Development Tribunal and Others (335/08) [2009] ZASCA 106 (22 September 2009) Johannesburg Metropolitan Municipality v Gauteng Development Tribunal and Others 20084 SA 572 (W)

Minister of Public Works v Kyalami Ridge Environmental Association 20013 SA 1151 (CC)

Port Elizabeth Municipality v Peoples Dialogue on Land and Shelter 20002 SA 1074 (SEC)

Wary Holdings (Pty) Ltd v Stalwo (Pty) Ltd 20091 SA 337 (CC)

\section{Register of Government publications}

GN R1886 of 1990 Township development regulations for towns

GN R1888 of 1990 Land use and planning regulations

Land Use Management Bill GG 30979 of 15 April 2008 [B 27-2008] ISBN 978-

1-77037-230-6

Local Government: Municipal Planning and Performance Management

Regulations GN R 796 GG 22605 of 24 August 2001

Proc R1897 of 1986 Regulations relating to township establishment and land use

White paper on South African land policy (1997)

Wise land use: White paper on spatial planning, land use management and land development GG 22473 of 20 July 2001

\section{Register of national legislation}

Black Administration Act 38 of 1927

Black Communities Development Act 4 of 1984

Constitution of the Republic of South Africa, 1996

Development Facilitation Act 67 of 1995 
Local Government: Municipal Systems Act 32 of 2000

Subdivision of Agricultural Land Act 70 of 1970

\section{Register of provincial legislation}

Gauteng Planning and Development Act 3 of 2003

KwaZulu-Natal Planning and Development Act 6 of 2008

Land Use Planning Ordinance 15 of 1985 (C)

Northern Cape Planning and Development Act 7 of 1998

Town-planning and Townships Ordinance 15 of 1986 (T)

Town Planning Ordinance 27 of 1949 (N)

Townships Ordinance 9 of 1969 (OFS)

\section{Register of Internet sources}

"Developers challenge city over its move on key building Act" (year unknown) www.snymans.com

"Developers challenge city over its move on key building Act" www.snymans.com/news/developers [date of use 28 September 2009]

\section{List of Abbreviations}

CoJ City of Johannesburg Metropolitan Municipality

SAPL South African Public Law

Stell LR Stellenbosch Law Review

JCRDL Journal of Contemporary Roman-Dutch Law 